\title{
Chronic intestinal inflammation: inflammatory bowel disease and colitis-associated colon cancer
}

\author{
Deborah C. Rubin ${ }^{1,2}{ }^{*}$, Anisa Shaker ${ }^{1}$ and Marc S. Levin ${ }^{1,3}$ \\ ${ }^{1}$ Division of Gastroenterology, Department of Internal Medicine, Washington University School of Medicine, Saint Louis, MO, USA \\ 2 Department of Developmental Biology, Washington University School of Medicine, Saint Louis, MO, USA \\ ${ }^{3}$ Saint Louis Veterans Administration Medical Center, Saint Louis, MO, USA
}

\section{Edited by:}

Masaaki Murakami, Osaka University, Japan

\section{Reviewed by:}

Daisuke Kamimura, Osaka University, Japan

Hisako Kayama, Osaka University, Japan

\section{${ }^{*}$ Correspondence}

Deborah C. Rubin, Division of Gastroenterology, Department of Internal Medicine, Washington University School of Medicine, 660 South Euclid Avenue, Box 8124, Saint Louis, MO 63110, USA. e-mail:drubin@dom.wustl.edu
The inflammatory bowel diseases (IBD), including Crohn's disease (CD) and ulcerative colitis (UC), are chronic inflammatory disorders of the intestine. The prevalence in the United States is greater than 200 cases per 100,000, with the total number of IBD patients between 1 and 1.5 million. CD may affect all parts of the gastrointestinal tract, from mouth to anus, but most commonly involves the distal part of the small intestine or ileum, and colon. UC results in colonic inflammation that can affect the rectum only, or can progress proximally to involve part of or the entire colon. Clinical symptoms include diarrhea, abdominal pain, gastrointestinal bleeding, and weight loss. A serious long-term complication of chronic inflammation is the development of colorectal cancer. A genetic basis for IBD had long been recognized based on the increased familial risk. However, significant discordance for $C D$ in twins, and a much less robust phenotypic concordance for UC, suggested additional factors play a role in disease pathogenesis, including environmental factors. In the past several years, progress in understanding the molecular basis of IBD has accelerated, beginning with the generation of animal models of colitis and progressing to the identification of specific genetic markers from candidate gene, gene linkage, and genome-wide association analyses. Genetic studies have also resulted in the recognition of the importance of environmental factors, particularly the crucial role of the gut microbiota in $C D$ and UC. Altered immune responses to the normal intestinal flora are key factors in IBD pathogenesis. In this research topic, the genetic basis of $\mathrm{IBD}$, the genetic and cellular alterations associated with colitis-associated colon cancer, and the emerging role of the intestinal microbiota and other environmental factors will be reviewed.

Keywords: inflammatory bowel disease, chronic intestinal inflammation, colitis-associated colon cancer, Crohn's disease, ulcerative colitis

\section{INTRODUCTION}

The inflammatory bowel diseases (IBD), including Crohn's disease (CD) and ulcerative colitis (UC), are chronic inflammatory disorders of the intestine. The prevalence in the United States is greater than 200 cases per 100,000 for each disorder, with the total number of IBD patients between 1 and 1.5 million (Kappelman et al., 2007; Loftus Jr., 2007). CD may affect all parts of the gastrointestinal tract, from mouth to anus, but most commonly involves the distal part of the small intestine or ileum, and colon. UC results in colonic inflammation that can affect the rectum only (proctitis) or can cause continuous disease from the rectum proximally, to involve part of or the entire colon. Clinical symptoms include diarrhea, abdominal pain, gastrointestinal bleeding, and weight loss. A serious long-term complication of chronic inflammation is the development of colorectal cancer (CRC).

A genetic basis for IBD had long been recognized based on the increased familial risk, with a $5-30 \%$ incidence in families of affected individuals (Duerr, 2002) as well as $50-75 \%$ phenotypic concordance in monozygotic twins with CD (Tysk et al., 1988). A family history of IBD is more commonly found in patients with $\mathrm{CD}$ compared to UC (Duerr, 2002). However, significant discordance for $\mathrm{CD}$ in twins, as well as a much less robust phenotypic concordance for UC in twins (Tysk et al., 1988; Orholm et al., 2000), also suggested additional factors play a role in disease pathogenesis, including a significant impact of environmental factors. In the past several years, progress in understanding the molecular basis of IBD has accelerated markedly, beginning with the generation of rodent transgenic and mouse knockout models of colitis and progressing to the identification of specific genetic markers from candidate gene approaches, gene linkage, and genome-wide association analyses (Tysk et al., 1988; Duerr et al., 2006; Barrett et al., 2008; Fisher et al., 2008; Anderson et al., 2009; Silverberg et al., 2009; Franke et al., 2010). It has become increasingly clear that IBD is a polygenic, complex disorder with region- and ethnic-specific differences in genetic risk factors (Abraham and Cho, 2009). In addition, genetic studies have resulted in the recognition of the importance of environmental factors, particularly focusing on the critical importance of the gut microbiota in CD and UC (Nell et al., 2010). Altered immune responses to the normal intestinal flora of the gut are key factors in $\mathrm{CD}$ pathogenesis. 
Chronic inflammation is also associated with malignancy and has been proposed to be a major contributor to a multitude of cancers (Coussens and Werb, 2002; Kundu and Surh, 2008; Mantovani etal., 2008; Danese and Mantovani, 2010; Solinas et al., 2010). Chronic colonic inflammation from UC or CD results in a well-recognized increased risk of colon carcinogenesis (Bernstein et al., 2001; Eaden et al., 2001; Itzkowitz and Yio, 2004; Ullman and Itzkowitz, 2011). CD is also associated with an increased risk of small bowel adenocarcinoma, due to chronic inflammation of the small intestine. The cumulative probability of CRC in UC patients has been shown in meta-analysis to range from $2 \%$ after 10 years of disease, up to $18 \%$ after 30 years of disease (Eaden et al., 2001; Feagins et al., 2009; Westbrook et al., 2010). Patients with Crohn's colitis also have an increased cumulative risk for CRC, from 2.9\% at 10 years to $8.3 \%$ after 30 years of disease (Canavan et al., 2006). The risk of carcinogenesis is related to severity, extent, and duration of disease (Rutter et al., 2004). Patients are advised to undergo colonoscopy with a specific biopsy protocol, performed every 1-2 years after 8-10 years of disease to detect dysplasia and rule out carcinogenesis. Unlike in sporadic colorectal carcinoma, in which the dysplastic lesion is an adenomatous polyp, dysplasia in IBD can be flat or polypoid. Flat lesions can be particularly difficult to detect endoscopically, and more sensitive markers of dysplasia are still lacking and represent a major focus of current research. Because of the frequency of IBD, the early onset of disease and the significantly increased risk for carcinogenesis, the health, emotional, and economic burden is quite high.

In this review, the genetic basis of IBD, the genetic and cellular alterations associated with chronic inflammation-induced colon cancer, and the emerging role of the intestinal microbiota and other environmental factors will be reviewed.

\section{CLINICAL CHARACTERISTICS OF THE INFLAMMATORY BOWEL DISEASES \\ CLINICAL CHARACTERISTICS COMMON TO ULCERATIVE COLITIS AND CROHN'S DISEASE}

The peak age of incidence for IBD is between 16 and 30 years (Kuster etal., 1989). Both UC and CD can affect the colon, and patients with either UC or CD have an increased risk of colitis-associated cancer (CAC) after 8-10 years from the time of diagnosis. Symptoms of active disease include diarrhea and abdominal pain. Although both CD and UC patients can experience gastrointestinal bleeding, in UC hematochezia or the presence of visible bleeding is more common than in $\mathrm{CD}$, in which there is occult or microscopic blood loss. Extraintestinal manifestations of IBD include arthralgias and arthritis, skin diseases such as erythema nodosum and pyoderma gangrenosum, ocular disorders including uveitis and iritis, and sclerosing cholangitis, in which there is inflammation of the liver's bile ducts. Urinary excretion of oxalate may be elevated in patients with $\mathrm{CD}$, resulting in kidney stones, in patients who have not had a colectomy. Both UC and $\mathrm{CD}$ patients may develop strictures in the colon (UC or CD) or small bowel (CD only).

\section{CLINICAL CHARACTERISTICS SPECIFIC TO CROHN'S DISEASE}

Patients with CD suffer the consequences of a transmural inflammatory process and thus are at risk for fistulizing disease. Fistulas, which are communications between the gastrointestinal tract and other organs, may form between the bowel and bladder or the vagina, (e.g., enterovesicular or recto-vaginal fistulas), from the intestines to the skin (enterocutaneous fistulas), or from intestine to intestine (enteroenteric fistulas). Perianal disease is common and can be debilitating and refractory to treatment. Due to the transmural nature of the inflammatory process and involvement of the small intestine which is responsible for nutrient absorption, patients with $\mathrm{CD}$ are more prone to weight loss, nutrient deficiencies, and in children, growth retardation, especially after glucocorticoid therapy. Other serious complications include perforation or microperforation of the small or large bowel which may result in abscess formation. Surgical resection of the colon is not curative because CD can affect all parts of the gastrointestinal tract from mouth to anus. Pathological features specific to CD include the presence of granulomas on biopsy of the small bowel or colon.

\section{CLINICAL CHARACTERISTICS SPECIFIC TO ULCERATIVE COLITIS}

Colonic inflammation in UC is continuous, beginning in the rectum. Gross gastrointestinal bleeding is much more common in UC. The development of toxic megacolon is a dreaded complication of active inflammation, which may lead to emergent colectomy. Unlike in CD, colectomy is curative in UC.

\section{MOUSE MODELS OF INFLAMMATORY BOWEL DISEASE CHEMICAL MODELS}

Mouse models of colitis and CAC have proven in selected circumstances to be relevant to the pathogenesis of these disorders in humans, have led to the identification of critical genetic factors and have provided a means for understanding the role of specific genes identified by linkage or genome-wide association studies. Two of the most widely used, non-genetic colitis models are the dextran sodium sulfate (DSS)-induced chemical injury model, and the trinitrobenzene sulfonic acid (TNBS) hapten-induced model (Strober et al., 2002). These have been particularly useful in identifying and studying the role of genetic factors that modify colitis, because both DSS and TNBS can be administered to genetically altered (knockout or transgenic) mice to rapidly induce colonic inflammation and ulceration resembling UC (Strober et al., 2002). DSS in drinking water induces an acute colitis within 5 days of exposure, and can also be utilized to mimic chronic colitis after repeated exposures. DSS in combination with azoxymethane (AOM) can be utilized to generate a mouse model of CAC (Greten et al., 2004; Neurath and Finotto, 2009). TNBS is administered by enema and results in a hapten-induced, interleukin-12 (IL-12) driven colitis (Neurath and Finotto, 2009).

\section{GENETIC MODELS}

The earliest murine genetic models of IBD were generated in mice in which the $\mathrm{T}$ cell receptor was inactivated (Mombaerts et al., 1993), IL-10 (Kuhn et al., 1993) or IL-2 (Sadlack et al., 1993) was deleted, or tumor necrosis factor-alpha $\left(\mathrm{TNF} \alpha^{\triangle \mathrm{ARE}}\right.$ mice) was over-produced. These mice develop colitis after variable lengths of time, and a seminal discovery was the observation that in almost every genetic model, the microbiota are required for induction 
of colitis (reviewed in Nell etal., 2010). Mice raised in either a germ-free environment (e.g., IL-10 mice; Sellon et al., 1998) or treated with antibiotics were protected from colitis. Subsequently, a plethora of mouse IBD models have been described, resulting from gene knockout or transgenic overexpression. As summarized in Rosenstiel et al. (2009), some mouse models correlate well with human disease risk loci or associated pathways, whereas others do not yet have clear relevance to human clinical syndromes.

\section{GENETICS OF INFLAMMATORY BOWEL DISEASE}

Exciting advances in the understanding of the complex genetics of IBD have resulted from comprehensive genetic studies including linkage and genome-wide association analyses. These have led to the identification of several predicted as well as novel pathways involved in CD and UC pathogenesis. For example, the critical roles of innate immunity and autophagy as well as epithelial barrier function have been supported by the identification of risk alleles in genes from these pathways, by genome-wide association studies (e.g., Duerr et al., 2006; Barrett et al., 2008; Silverberg et al., 2009). A complete list of genetic loci linked to IBD susceptibility (Kaser et al., 2010) shows that some are specific to $\mathrm{CD}$, some to UC, and some are linked to both diseases.

\section{INNATE IMMUNITY NOD2/CARD15}

A seminal discovery in unraveling the complex genetics underlying CD was that mutations in the NOD2/CARD15 gene locus are associated with risk for CD in Caucasian populations of European ancestry (Hugot et al., 2001; Ogura et al., 2001), and particularly for ileal disease (Lesage et al., 2002). Mutations in NOD2 are not sufficient for generating CD, as a significant proportion of the normal population has NOD2 mutations but are not affected by this disorder. However, individuals who are heterozygous for a NOD2 polymorphism have an increased risk of CD by a factor of 1.7-4, and homozygosity confers a risk factor of 11-27 (Economou et al., 2004). NOD2/CARD15 is a member of a family of cytosolic receptors containing a central nucleotide binding and oligomerization domain (NOD), an N-terminal effector binding domain, and leucine-rich repeats. These and other pattern recognition receptors, expressed in the epithelium and in a variety of immune cells, have important functions in innate immunity, particularly in regulating responses to intracellular pathogens and other exogenous injury-inducing stimuli. NOD2 recognizes components of the bacterial cell wall and elicits an NF- $\kappa \mathrm{B}$ response, and also mediates the release of defensins, which are antimicrobial peptides. Mutations which impair NOD2 function result in defective downregulation of pro-inflammatory cytokines that normally occurs during chronic NOD2 stimulation (Hedl et al., 2007). In addition, in macrophages, others have shown that NOD2 is a negative regulator of Toll-like receptor 2 (TLR2)-mediated activation of NF-кB-c-Rel (Watanabe et al., 2004). However, the mechanisms by which loss of function mutations result in CD are still under investigation (Abraham and Cho, 2009). The discovery of this association led to further recognition of the importance of the microbiome in CD pathogenesis.

\section{Autophagy genes ATG16 autophagy related 16-like 1 (ATG16L1) and immunity related GTPase family $M$}

Genome-wide association studies have shown that polymorphisms in the ATG16L1 gene (Hampe et al., 2007) and sequence variants in the IRGM gene (Parkes et al., 2007) are linked to CD. These genes encode proteins that are critical for autophagy, a process that mediates degradation of intracellular proteins via vesicle-mediated delivery to the lysosome (reviewed in Glick et al., 2010; Huett etal., 2010). Autophagy is particularly important for defense against intracellular pathogens. A mouse model of ATG16L1 deficiency showed Paneth cell dysfunction with aberrant exocytosis, as well as an altered transcriptional profile, characterized by increased expression of pro-inflammatory cytokines and lipid metabolism genes. Patients with CD have a similar Paneth cell phenotype (Cadwell et al., 2008). An important observation derived from the ATG16L1 mouse model was that viral infection with murine norovirus, as well as the presence of commensal bacteria, were required for generating these specific Paneth cell abnormalities (Miller et al., 2008). Germ-free mice have normal Paneth cells and viral infection in the presence of commensal bacteria induced the characteristic changes in Paneth cell function. IRGM functions to protect cells from mycobacteria (Singh et al., 2006). These data provide further support for the hypothesis that microbial/viral interactions with the intestinal mucosa are required for disease generation, and suggest that combinatorial models for IBD pathogenesis are most relevant for the study of human disease pathogenesis.

\section{Intelectin 1 or ITLN1}

Genome-wide association studies have also identified an association between intelectin 1 and CD. Intelectin 1 is a lectin that recognizes galactofuranosyl residues in bacterial cell walls and is identical to human lactoferrin receptor (Tsuji et al., 2001). It is a lipid raft protein that resides in the enterocytic brush border and is also expressed in Paneth and goblet cells of the small bowel (Wrackmeyer et al., 2006). Its presumed function is to protect from parasitic infection and offer cytoprotection from bacterial translocation.

\section{INFLAMMATORY/CYTOKINE SIGNALING PATHWAYS IL-23 RECEPTOR, INTERLEUKIN 12B, AND OTHER GENES INVOLVED IN IL-23 SIGNALING AND T HELPER CELL 17 FUNCTION}

Genome-wide association studies have shown an association between $I L 23 R$ and CD (Duerr et al., 2006). This gene encodes a subunit of the IL-23 receptor (IL-23R) complex, which consists of the IL-23R and the IL-12 receptor B1. IL-23 is a pro-inflammatory cytokine that results in activation of Janus-associated kinase (JAK) 2 and signal transducers and activators of transcription 3 (STAT3), which are important downstream mediators of inflammation. The likely relevance of IL-23R to CD is suggested by its known biological functions, e.g., IL-23 expression is required for murine colitis (Yen et al., 2006), and IL-23 is important for T helper cell 17 (Th17) cell function and production of IL-17. IL-17 expression is increased in colons from patients with UC and CD (Fujino et al., 2003), and other members of IL-23R regulated pathways are linked to both UC and CD, e.g., STAT3, JAK 2, and IL12B (Barrett et al., 2008). In addition, the chemokine receptor CCR6 is also 
implicated in $\mathrm{CD}$, and is expressed by immature dendritic cells and memory T cells (Barrett et al., 2008).

\section{Interleukin-10}

Interleukin-10 is an anti-inflammatory cytokine that has long been postulated to play a role in IBD. One of the first mouse models of IBD resulted from the generation of the IL-10 knockout mouse, which develops spontaneous inflammation (Kuhn et al., 1993), and which is dependent upon the presence of gut bacteria. Regulatory T cells (Tregs) express IL-10; selective deletion of IL-10 expression in Tregs results in spontaneous colitis and inflammation at other epithelial surfaces including skin and lungs (Rubtsov et al., 2008). Genome-wide association studies for UC have shown SNPs flanking the IL-10 gene to be linked to UC (Franke et al., 2008b). In addition, patients with early onset IBD (at less than 1 year of age) had mutations in the IL10RA and IL10RB genes, which resulted in abrogated STAT3 phosphorylation from deficient IL-10 signaling (Glocker et al., 2009). Interestingly, the phenotype of these patients is closest to $\mathrm{CD}$, yet genome-wide association studies have not identified IL-10 as a susceptibility locus. However, these data all support a key role for IL-10 in IBD and suggest that future therapeutic trials with IL-10 may be warranted.

\section{NKX2.3}

Genome-wide association studies have shown that this homeodomain transcription factor is associated with $\mathrm{CD}$ and $\mathrm{UC}$ (Barrett etal., 2008; Franke etal., 2008a). Mice that are null for $N k \times 2.3$ have defective splenic and intestinal development. Homozygous null mice exhibit a marked delay in villus formation with crypt hypoproliferation. A subset of mice survive to adulthood and show massive hyperproliferation of the gut with decreased Bmp2 and Bmp4 expression (Pabst et al., 1999). Splenic development is markedly abnormal, in these mice, resulting in either small or completely absent spleens. Although the phenotype associated with NKX2.3 mutations in humans has not been defined, mouse models suggest gut epithelial or splenic functional defects.

\section{T CELL-MEDIATED RESPONSES}

$\mathrm{T}$ helper cells differentiate into two distinct subtypes, Th1 and Th2 cells. These cells produce characteristic sets of cytokines. Many years of investigation has shown that Th1 cytokines are expressed in CD, whereas UC is a Th2 cytokine-mediated disease. A review of this vast body of research is beyond the scope of this manuscript, and is discussed in detail in other reviews (e.g., Strober and Fuss, 2011).

\section{ENVIRONMENTAL RISK FACTORS SMOKING}

Smoking has emerged as one of the critically important risk factors for IBD, with an interesting paradoxical relationship for UC vs. $\mathrm{CD}$ disease activity. Smoking clearly increases the risk of CD activity (Calkins, 1989) and increases risk of recurrence after surgery (Unkart et al., 2008), yet appears to be protective for UC (Harries et al., 1982; Calkins, 1989). Nicotine has been studied as a primary treatment for UC (Pullan et al., 1994; Sandborn et al., 1997). Carbon monoxide, an important component of cigarette smoke, has been shown to suppress colonic pro-inflammatory cytokine production, and increase IL-10 secretion, through heme oxygenase-1 dependent pathways (Sheikh et al., 2011).

\section{THE MICROBIOME}

Bacterial, mycobacterial, or viral infections have long been postulated to be important in IBD pathogenesis (Lidar et al., 2009). A common feature of almost all rodent models of IBD is that treatment with antibiotics or rederivation of knockout or transgenic mice into germ-free conditions markedly mitigates disease activity (e.g., Taurog et al., 1994; Strober et al., 2002). Antibiotics can ameliorate disease activity in humans, and for certain complications of $\mathrm{CD}$ such as fistulizing disease, metronidazole is an important therapeutic agent. Viral infection is required to generate the Paneth cell defects found in ATG16L1 mice (Cadwell et al., 2010) suggesting that in addition to human bacterial microbiota, viral or fungal commensals may play a role in IBD pathogenesis.

\section{Associations with single microorganisms}

Microbial association studies in mouse models and analysis of intestinal mucosa or blood from patients with $\mathrm{CD}$ have implicated single pathogenic bacterial species in IBD pathogenesis, although none have yet been proven to be causative (reviewed in Lidar etal., 2009; Reiff and Kelly, 2010). The microorganisms most frequently implicated include Mycobacterium avium subspecies paratuberculosis, Saccharomyces cerevisiae, Candida albicans, adherent enteroinvasive Escherichia coli, and Chlamydia pneumoniae.

\section{The microbiome in normal intestine and in inflammatory bowel disease}

Recent discoveries implicating genes such as NOD2 in the pathogenesis of $\mathrm{CD}$ have led to the recognition that the pathogenesis of IBD involves loss of tolerance to commensal organisms and enhanced immune responses to bacterial antigens. The intestine is colonized by the largest bacterial burden in the body, containing approximately 100 trillion organisms (Gill et al., 2006). Bacteria belonging to the Firmicutes (Gram-positive bacteria) and Bacteroidetes (Gram-negative bacteria) phyla are the two major groups in mammalian intestine (Backhed et al., 2005; Turnbaugh et al., 2007). Proteobacteria (which include Helicobacter and Escherichia) and Actinobacteria are also significant contributors to the gut flora. Multiple studies have shown that the gut microbiota is altered in IBD patients. For example, biopsy samples from $\mathrm{CD}$ patients were used to prepare bacterial DNA which was amplified using universal bacterial $16 \mathrm{~S}$ rRNA primers (Gophna etal., 2006). A significant increase in Proteobacteria and Bacteroidetes was found in CD patients compared to controls, with a decrease in Clostridia. Metagenomic approaches were used to analyze fecal samples from Crohn's patients and healthy donors, and revealed reduced complexity of the Firmicutes in affected patients (Manichanh et al., 2006). Evaluation of the microbial populations in surgically resected tissue samples of small bowel and colon from Crohn's, UC, and non-IBD controls, by rRNA sequence analysis, showed that specific flora were not enriched in small bowel or colon from IBD patients. However, a subset of IBD samples showed alterations 
in the representation of the Bacteroidetes and Firmicutes (Eckburg and Relman, 2007; Frank et al., 2007, 2011). Analysis of fecal samples from IBD patients compared to healthy subjects (Qin et al., 2010.) showed reduced bacterial diversity and altered bacterial species abundance, using metagenomic sequencing methods

\section{Role of Toll-like receptors and nucleotide-binding oligomerization domain protein-like receptors}

Toll-like receptors and NLRs are innate receptors that play an important role in recognizing commensal bacteria. Recognition of commensals by TLRs and NLRs has been shown to be critical for maintaining intestinal epithelial integrity and homeostasis. For example, mice deficient in the adaptor protein, MyD88, develop severe colitis following DSS administration (Rakoff-Nahoum et al., 2004). Inflammasomes composed of NLR proteins sense damageassociated molecular patterns. NLRP6 inflammasome-deficient mice had more severe colitis, reduced IL-18 levels, and altered gut microbiota (Elinav et al., 2011).

\section{COLITIS/INFLAMMATION-ASSOCIATED DYSPLASIA AND CANCER \\ RELATIONSHIP TO COLORECTAL CANCER}

The pathogenetic mechanisms underlying CAC compared to familial or sporadic CRC have significant similarities, but major differences have also been recognized (Feagins et al., 2009; Terzic et al., 2010; Ullman and Itzkowitz, 2011). Whereas dysplasia in CRC is focal, multiple areas of the colon are often involved in CAC, indicating a broader "field effect." Linkage analyses of families with rare, inherited early-onset CRC led to the identification of gene mutations which are highly relevant to the much more common sporadic CRC. In many circumstances, mutations in these genes also occur in CAC, but at a different stage of the disease, and other gene mutations are specific to CRC only. A seminal discovery in CRC pathogenesis was that inherited mutations in the adenomatous polyposis coli (APC) gene result in familial adenomatous polyposis or FAP, in which affected patients develop hundreds of adenomatous polyps and are at high risk for early death from CRC (Groden et al., 1991). APC mutations occur in sporadic CRC and are one of the earliest events in CRC pathogenesis. APC mutations are also found in CAC, but generally occur much later in the disease course (Redston et al., 1995; Tarmin et al., 1995; Aust et al., 2002). On the other hand, KRAS and DCC/DPC4 mutations occur in both CAC and CRC (Ullman and Itzkowitz, 2011). P53 mutations are commonly found in CACs. P53 mutation is an early event that precedes loss of heterozygosity and is highly associated with aneuploidy (Brentnall et al., 1994). Chronic inflammation associated with increased pro-inflammatory cytokine release and signaling plays a critical role in the initiation of CAC, but sporadic CRC tumors also exhibit inflammatory infiltrates and activated immune response pathways (Terzic et al., 2010). These observations have led to the postulation that inflammation promotes tumorigenesis both extrinsically (driven by chronic inflammatory conditions such as IBD) and intrinsically (driven by inflammation and inflammatory cells recruited to and contained within tumors; Mantovani et al., 2008; Danese and Mantovani, 2010).

\section{MOUSE MODELS OF COLITIS-ASSOCIATED CANCER}

One of the most widely utilized mouse models of CAC is the AOM/DSS model (Becker et al., 2004; Greten et al., 2004; Suzuki et al., 2006; Neufert et al., 2007; Tanaka et al., 2008); AOM is a chemical carcinogen that acts by alkylation of DNA. It is further metabolized by the liver after intraperitoneal injection and is excreted in the bile. Additional metabolism by the bacterial flora further activates its carcinogenicity (Neufert et al., 2007). Multiple injections of AOM result in distal colonic tumorigenesis with histologic characteristics similar to human CRC. To mimic CAC, mouse models were developed that use AOM in combination with DSS, which when included in the drinking water, induces colitis, as above. The first models used AOM injection followed by one cycle of DSS. However, to further mimic states of chronic inflammation, AOM injection was combined with three cycles of DSS, which induces a chronic colitis. This model accelerates tumor formation and results in larger tumor size. Of interest, there are differences in susceptibility among mouse strains (Suzuki et al., 2006) and the formation of tumors in the same strain may vary among mouse facilities, suggesting that tumorigenesis is affected by microflora.

\section{PATHOGENESIS AND MOLECULAR BIOLOGY OF COLITIS-ASSOCIATED CANCER}

Cancer associated with chronic inflammation, similar to other cancers, is characterized by a loss of normal growth regulation, resulting from a series of genetic mutations and epigenetic alterations in important cancer-related regulatory genes. The cancer stem cell model postulates that expansion of stem cells occurs in response to these mutations, resulting in tumor formation. The mechanisms by which inflammation results in carcinogenesis are presently the focus of intense research. Multiple pathways are likely to play a role, including production of reactive oxygen species and cytokine and chemokine expression by immune cells, which increase the risk of mutagenesis, and interactions between cancer stem cells and the local tumor microenvironment, including immune cells and myofibroblasts (Shaker et al., 2010; Vermeulen et al., 2010; Worthley et al., 2010; Quante et al., 2011; Shaker and Rubin, 2011). Inflammation also affects DNA methylation patterns and histone modification. Cyclo-oxygenase 2, which metabolizes arachidonic acid to prostaglandins, exhibits increased expression in inflamed tissues and affects cell proliferation, apoptosis, and angiogenesis. Genetic factors also play a role as IBD patients with a family history of CRC have an additional increase in risk for CAC, suggesting overlapping mechanisms.

\section{ROLE OF THE MICROBIOME, TLRS, AND NLRS}

In addition to playing an important role in IBD, TLRs and NLRs also contribute to the pathogenesis of CAC. For example, MyD88 signaling appears to be protective in the AOM/DSS model of CAC; $M y d 88^{-/-}$mice had increased polyp numbers compared to controls, and developed infiltrating carcinomas (Salcedo et al., 2010). In addition, derepression of the inflammasome in Casp12-/- mice, resulted in enhanced epithelial repair processes with increased proliferation, increased inflammation and increased susceptibility to AOM/DSS CAC (Dupaul-Chicoine et al., 2010). 


\section{ROLE OF OXIDATIVE STRESS, CYTOKINES, AND CHEMOKINES}

Inflammatory cells produce a variety of reactive oxygen and nitrogen species which may generate gene mutations and DNA damage, contributing to carcinogenesis (Kawanishi et al., 2006; Kundu and Surh, 2008; Mantovani et al., 2008; Colotta et al., 2009). For example, mice which sustain DNA damage from inflammation and which are deficient in base excision repair enzymes have increased tumor multiplicity in the AOM/DSS mouse model of CAC, indicating that inflammation can induce DNA damage which in turn contributes to colon carcinogenesis (Liao et al., 2008; Meira et al., 2008). Direct genotoxicity was documented in mouse models of intestinal inflammation, which correlated with the degree of systemic and local inflammation, and was associated with evidence of reactive oxygen species-mediated oxidative stress and DNA damage (Westbrook et al., 2010). On the other hand, the role of nitric oxide is less clear. Mice which lack inducible nitric oxide synthase, the enzyme that generates nitric oxide $\left(\mathrm{NOS}^{-/-}\right.$mice), when bred to $I L 10^{-/-}$mice (which spontaneously develop colitis and adenocarcinoma with aging), had higher numbers of polyps compared to $I L-10^{-/-}$mice alone, suggesting that nitric oxide may be protective (Zhang et al., 2007). However, increased production of reactive oxygen and nitrogen species may also result in oncogene activation or tumor suppressor inactivation by inducing mutations in critical regulatory genes. For example, p53 mutations in codons 247 and 248 were found in inflamed colons of UC patients, associated with increased iNOS expression (Hussain et al., 2000).

The major cytokines that play the best-described role in promoting inflammation in CAC include TNF $\alpha$, IL-1, and IL-6 (Greten et al., 2004; Grivennikov et al., 2009; Shaker et al., 2010). TNF $\alpha$ signaling via NF- $\mathrm{B}$ pathways mediated downstream by IL-6 and STAT3 appear to play an important role in this disorder (Ullman and Itzkowitz, 2011).

\section{GENE SILENCING BY METHYLATION OR BY miRNA}

An important mechanism of tumorigenesis is epigenetic silencing of selected genes such as tumor suppressor genes, by promoter methylation or by microRNAs (miRNA). These include DNA mismatch repair (MMR) genes; hypermethylation is thought to be the mechanism responsible for loss of MMR activity. Loss of DNA MMR gene activity results in microsatellite instability, which is characterized by increased frameshift mutation rates. MMRdeficient tumors account for approximately 15\% of all CRCs and are characterized by a right sided location, have a lymphocytic infiltrate and have a poorly differentiated, mucinous, or signet cell histologic appearance.

\author{
REFERENCES \\ Abraham, C., and Cho, J. H. (2009). \\ Inflammatory bowel disease. N. Engl. \\ J. Med. 361, 2066-2078. \\ Anderson, C. A., Massey, D. C., \\ Barrett, J. C., Prescott, N. J., \\ Tremelling, M., Fisher, S. A., \\ Gwilliam, R., Jacob, J., Nimmo, \\ E. R., Drummond, H., Lees, C. \\ W., Onnie, C. M., Hanson, C., \\ Blaszczyk, K., Ravindrarajah, R.,
}

The methylation status of normal, inflamed, and dysplastic colonic tissue has been studied intensively. It has been proposed that gene methylation may be an early event in inflammationassociated tumorigenesis, and thus can potentially be a sensitive marker for predicting dysplasia. The methylation status of multiple genes has been examined, and generally, DNA methylation appears to be more frequent and is seen more commonly in non-neoplastic mucosa from UC patients with CAC, compared to non-neoplastic mucosa from UC patients without cancer. For example, the methylation status of RUNX2 and MINT1 was higher in non-neoplastic tissue of UC patients with CAC compared to non-neoplastic tissue of UC patients without cancer. In contrast, COX-2 was more frequently methylated in colons from UC patients without cancer compared to UC patients with cancer (Garrity-Park et al., 2010). Aging is associated with methylation and silencing of a panel of genes (including the estrogen receptor, MyoD, p16 exon1, and CSPG2). In non-dysplastic tissues from UC patients with high grade dysplasia, these genes also showed significantly higher degrees of methylation, compared to UC patients without dysplasia (Issa et al., 2001). Methylation of the estrogen receptor in non-neoplastic epithelium of UC patients with CAC occurred in a higher percentage compared to UC patients without cancer (Fujii et al., 2005). These data suggest that methylation status can be used as a biomarker for early detection of dysplasia, and also may help identify patients who are at increased risk for neoplasia.

\section{CONCLUSION}

Great progress has been made towards identifying the genetic basis for the IBD, and for understanding the interactions between the gut luminal/microbial environment and its epithelium. Future research will focus on understanding the function of identified disease risk genes and developing new targeted therapies. The burden of CAC continues to be high, and current research is focused on developing more sensitive markers of dysplasia. Intensive efforts will be focused on further delving into the mechanisms underlying the initiation of chronic inflammation-associated cancer, including the role of stromal-epithelial interactions within the unique environment of the gastrointestinal tract. As our understanding of gastrointestinal cancer stem cells progresses, so will our ability to optimally target the interactions between tumor epithelium and its microenvironment in CAC.

\section{ACKNOWLEDGMENTS}

The authors are supported by NIH NIDDK R01 DK 61216, 46122, 50466, and P30 DK 52574.

relationship. Gastroenterology 136 , 523-529.e3

Aust, D. E., Terdiman, J. P., Willenbucher, R. F., Chang, C. G., Molinaro-Clark, A., Baretton, G. B., Loehrs, U., and Waldman, F. M. (2002). The APC/betacatenin pathway in ulcerative colitisrelated colorectal carcinomas: a mutational analysis. Cancer 94, 1421-1427.
Backhed, F., Ley, R. E., Sonnenburg, J. L., Peterson, D. A., and Gordon, J. I. (2005). Host-bacterial mutualism in the human intestine. Science 307, 1915-1920.

Barrett, J. C., Hansoul, S., Nicolae, D. L., Cho, J. H., Duerr, R. H., Rioux J. D., Brant, S. R., Silverberg, M. S., Taylor, K. D., Barmada, M. M., Bitton, A., Dassopoulos, T., Datta, L. W. Green, T., Griffiths, A. M., Kistner 
E. O., Murtha, M. T., Regueiro, M. D., Rotter, J. I., Schumm, L. P., Steinhart, A. H., Targan, S. R., Xavier, R. J.; NIDDK IBD Genetics Consortium, Libioulle, C., Sandor, C., Lathrop, M., Belaiche, J., Dewit, O., Gut, I., Heath, S., Laukens, D., Mni, M., Rutgeerts, P., Van Gossum, A., Zelenika, D., Franchimont, D., Hugot, J. P., de Vos, M., Vermeire, S., Louis, E.; BelgianFrench IBD Consortium; Wellcome Trust Case Control Consortium, Cardon, L. R., Anderson, C. A., Drummond, H., Nimmo, E., Ahmad, T., Prescott, N. J., Onnie, C. M., Fisher, S. A., Marchini, J., Ghori, J., Bumpstead, S., Gwilliam, R., Tremelling, M., Deloukas, P., Mansfield, J., Jewell, D., Satsangi, J., Mathew, C. G., Parkes, M., Georges, M., and Daly, M. J. (2008). Genome-wide association defines more than 30 distinct susceptibility loci for Crohn's disease. Nat. Genet. 40, 955-962.

Becker, C., M. Fantini, C., Schramm, C., Lehr, H. A., Wirtz, S., Nikolaev, A., Burg, J., Strand, S., Kiesslich, R., Huber, S., Ito, H., Nishimoto, N., Yoshizaki, K., Kishimoto, T., Galle, P. R., Blessing, M., RoseJohn, S., and Neurath, M. F. (2004). TGF-beta suppresses tumor progression in colon cancer by inhibition of IL-6 trans-signaling. Immunity 21, 491-501.

Bernstein, C. N., Blanchard, J. F., Kliewer, E., and Wajda, A. (2001). Cancer risk in patients with inflammatory bowel disease: a population-based study. Cancer 91, 854-862.

Brentnall, T. A., Crispin, D. A., Rabinovitch, P. S., Haggitt, R. C., Rubin, C. E., Stevens, A. C., and Burmer, G. C. (1994). Mutations in the p53 gene: an early marker of neoplastic progression in ulcerative colitis. Gastroenterology 107, 369-378.

Cadwell, K., Liu, J. Y., Brown, S. L., Miyoshi, H., Loh, J., Lennerz, J. K., Kishi, C., Kc, W., Carrero, J. A., Hunt, S., Stone, C. D., Brunt, E. M., Xavier, R. J., Sleckman, B. P., Li, E., Mizushima, N., Stappenbeck, T. S., and Virgin, H. W. IV. (2008). A key role for autophagy and the autophagy gene Atg16l1 in mouse and human intestinal Paneth cells. Nature 456, 259-263.

Cadwell, K., Patel, K. K., Maloney, N. S., Liu, T. C., Ng, A. C., Storer, C. E., Head, R. D., Xavier, R., Stappenbeck, T. S., and Virgin, H. W. (2010). Virus-plus-susceptibility gene interaction determines Crohn's disease gene Atg16L1 phenotypes in intestine. Cell 141, 1135-1145.
Calkins, B. M. (1989). A meta-analysis of the role of smoking in inflammatory bowel disease. Dig. Dis. Sci. 34, 1841-1854.

Canavan, C., Abrams, K. R., and Mayberry, J. (2006). Meta-analysis: colorectal and small bowel cancer risk in patients with Crohn's disease. Aliment. Pharmacol. Ther. 23, 1097-1104.

Colotta, F., Allavena, P., Sica, A., Garlanda, C., and Mantovani, A. (2009). Cancer-related inflammation, the seventh hallmark of cancer: links to genetic instability. Carcinogenesis 30, 1073-1081.

Coussens, L. M., and Werb, Z. (2002). Inflammation and cancer. Nature $420,860-867$.

Danese, S., and Mantovani, A. (2010). Inflammatory bowel disease and intestinal cancer: a paradigm of the Yin-Yang interplay between inflammation and cancer. Oncogene 29, 3313-3323.

Duerr, R. H. (2002). The genetics of inflammatory bowel disease. Gastroenterol. Clin. North Am. 31, 63-76.

Duerr, R. H., Taylor, K. D., Brant, S. R., Rioux, J. D., Silverberg, M. S., Daly, M. J., Steinhart, A. H., Abraham, C., Regueiro, M., Griffiths, A., Dassopoulos, T., Bitton, A., Yang, H., Targan, S., Datta, L. W., Kistner, E. O., Schumm, L. P., Lee, A. T., Gregersen, P. K., Barmada, M. M., Rotter, J. I., Nicolae, D. L., and Cho, J. H. (2006). A genome-wide association study identifies IL23R as an inflammatory bowel disease gene. Science 314, 1461-1463.

Dupaul-Chicoine, J., Veretssian, G., Doiron, K., Bergstrom, K. S., McIntire, C. R., LeBlanc, P. M., Meunier, C., Turbide, C., Gros, P., Beauchemin, N., Vallance, B. A., and Saleh, M. (2010). Control of intestinal homeostasis, colitis, and colitisassociated colorectal cancer by the inflammatory caspases. Immunity 32 , 367-378.

Eaden, J. A., Abrams, K. R., and Mayberry, J. F. (2001). The risk of colorectal cancer in ulcerative colitis: a meta-analysis. Gut 48, 526-535.

Eckburg, P. B., and Relman, D. A. (2007). The role of microbes in Crohn's disease. Clin. Infect. Dis. 44, 256-262.

Economou, M., Trikalinos, T. A., Loizou, K. T., Tsianos, E. V., and Ioannidis, J. P. (2004). Differential effects of NOD2 variants on Crohn's disease risk and phenotype in diverse populations: a metaanalysis. Am. J. Gastroenterol. 99, 2393-2404.

Elinav, E., Strowig, T., Kau, A. L., Henao-Mejia, J., Thaiss, C. A., Booth,
C. J., Peaper, D. R., Bertin, J., Eisenbarth, S. C., Gordon, J. I., and Flavell, R. A. (2011). NLRP6 inflammasome regulates colonic microbial ecology and risk for colitis. Cell 145, 745-757.

Feagins, L. A., Souza, R. F., and Spechler, S. J. (2009). Carcinogenesis in IBD: potential targets for the prevention of colorectal cancer. Nat. Rev. Gastroenterol. Hepatol. 6, 297-305.

Fisher, S. A., Tremelling, M., Anderson, C. A., Gwilliam, R., Bumpstead, S., Prescott, N. J., Nimmo, E. R., Massey, D., Berzuini, C., Johnson, C., Barrett, J. C., Cummings, F. R., Drummond, H., Lees, C. W., Onnie, C. M, Hanson, C. E., Blaszczyk, K., Inouye, M., Ewels, P., Ravindrarajah, R., Keniry, A., Hunt, S., Carter, M., Watkins, N., Ouwehand, W., Lewis, C. M., Cardon, L.; Wellcome Trust Case Control Consortium, Lobo, A., Forbes, A., Sanderson, J., Jewell, D. P., Mansfield, J. C., Deloukas, P., Mathew, C. G., Parkes, M., and Satsangi, J. (2008). Genetic determinants of ulcerative colitis include the ECM1 locus and five loci implicated in Crohn's disease. Nat. Genet. 40, 710-712.

Frank, D. N., Robertson, C. E., Hamm, C. M., Kpadeh, Z., Zhang, T., Chen, H., Zhu, W., Sartor, R. B., Boedeker, E. C., Harpaz, N., Pace, N. R., and Li, E. (2011). Disease phenotype and genotype are associated with shifts in intestinal-associated microbiota in inflammatory bowel diseases. Inflamm. Bowel Dis. 17, 179-184.

Frank, D. N., St Amand, A. L., Feldman, R. A., Boedeker, E. C., Harpaz, N., and Pace, N. R. (2007). Molecular-phylogenetic characterization of microbial community imbalances in human inflammatory bowel diseases. Proc. Natl. Acad. Sci. U.S.A. 104, 13780-13785.

Franke, A., Balschun, T., Karlsen, T. H., Hedderich, J., May, S., Lu, T., Schuldt, D., Nikolaus, S., Rosenstiel, P., Krawczak, M., and Schreiber, S. (2008a). Replication of signals from recent studies of Crohn's disease identifies previously unknown disease loci for ulcerative colitis. Nat. Genet. 40, 713-715.

Franke, A., Balschun, T., Karlsen, T. H., Sventoraityte, J., Nikolaus, S., Mayr, G., Domingues, F. S., Albrecht, M., Nothnagel, M., Ellinghaus, D., Sina, C., Onnie, C. M., Weersma, R. K., Stokkers, P. C., Wijmenga, C., Gazouli, M., Strachan, D., McArdle, W. L., Vermeire, S., Rutgeerts, P., Rosenstiel, P., Krawczak, M., Vatn, M. H.; IBSEN study group, Mathew, C. G., and Schreiber, S. (2008b).
Sequence variants in IL10, ARPC2 and multiple other loci contribute to ulcerative colitis susceptibility. Nat. Genet. 40, 1319-1323.

Franke, A., McGovern, D. P., Barrett, J. C., Wang, K., Radford-Smith, G. L., Ahmad, T., Lees, C. W., Balschun, T., Lee, J., Roberts, R., Anderson, C. A., Bis, J. C., Bumpstead, S., Ellinghaus, D., Festen, E. M., Georges, M. Green, T., Haritunians, T., Jostins, L. Latiano, A., Mathew, C. G., Montgomery, G. W., Prescott, N. J., Raychaudhuri, S., Rotter, J. I., Schumm, P., Sharma, Y., Simms, L. A., Taylor, K. D., Whiteman, D., Wijmenga, C., Baldassano, R. N., Barclay, M., Bayless, T. M., Brand, S., Büning, C., Cohen, A., Colombel, J. F., Cottone, M., Stronati, L., Denson, T., De Vos, M., D’Inca, R., Dubinsky, M., Edwards, C., Florin, T., Franchimont, D., Gearry, R., Glas, J., Van Gossum, A., Guthery, S. L., Halfvarson, J., Verspaget, H. W., Hugot, J. P., Karban, A., Laukens, D., Lawrance, I., Lemann, M., Levine, A., Libioulle, C., Louis, E., Mowat, C., Newman, W., Panés, J., Phillips, A., Proctor, D. D., Regueiro, M., Russell, R., Rutgeerts, P., Sanderson, J., Sans, M. Seibold, F., Steinhart, A. H., Stokkers, P. C., Torkvist, L., Kullak-Ublick, G., Wilson, D., Walters, T., Targan, S. R., Brant, S. R., Rioux, J. D., D’Amato, M., Weersma, R. K., Kugathasan, S., Griffiths, A. M., Mansfield, J. C., Vermeire, S., Duerr, R. H., Silverberg, M. S., Satsangi, J., Schreiber, S., Cho, J. H., Annese, V., Hakonarson, H., Daly, M. J., and Parkes, M. (2010). Genome-wide meta-analysis increases to 71 the number of confirmed Crohn's disease susceptibility loci. Nat. Genet. 42, 1118-1125.

Fujii, S., Tominaga, K., Kitajima, K., Takeda, J., Kusaka, T., Fujita, M., Ichikawa, K., Tomita, S., Ohkura, Y., Ono, Y., Imura, J., Chiba, T., and Fujimori, T. (2005). Methylation of the oestrogen receptor gene in non-neoplastic epithelium as a marker of colorectal neoplasia risk in longstanding and extensive ulcerative colitis. Gut 54, 1287-1292.

Fujino, S., Andoh, A., Bamba, S., Ogawa, A., Hata, K., Araki, Y., Bamba, T., and Fujiyama, Y. (2003). Increased expression of interleukin 17 in inflammatory bowel disease. Gut 52, 65-70. Garrity-Park, M. M., Loftus, E. V. Jr., Sandborn, W. J., Bryant, S. C., and Smyrk, T. C. (2010). Methylation status of genes in non-neoplastic mucosa from patients with ulcerative colitis-associated colorectal cancer. Am. J. Gastroenterol. 105, 1610-1619. Gill, S. R., Pop, M., Deboy, R. T., Eckburg, P. B., Turnbaugh, P. J., Samuel, 
B. S., Gordon, J. I., Relman, D. A., Fraser-Liggett, C. M., and Nelson, K. E. (2006). Metagenomic analysis of the human distal gut microbiome. Science 312, 1355-1359.

Glick, D., Barth, S., and Macleod, K. F. (2010). Autophagy: cellular and molecular mechanisms. J. Pathol. 221, 3-12.

Glocker, E. O., Kotlarz, D., Boztug, K., Gertz, E. M., Schäffer, A. A., Noyan, F., Perro, M., Diestelhorst, J., Allroth, A., Murugan, D., Hätscher, N., Pfeifer, D., Sykora, K. W., Sauer, M., Kreipe, H., Lacher, M., Nustede, R., Woellner, C., Baumann, U., Salzer, U., Koletzko, S., Shah, N., Segal, A. W., Sauerbrey, A., Buderus, S., Snapper, S. B., Grimbacher, B., and Klein, C. (2009). Inflammatory bowel disease and mutations affecting the interleukin-10 receptor. N. Engl. J. Med. 361, 2033-2045.

Gophna, U., Sommerfeld, K., Gophna, S., Doolittle, W. F., and Veldhuyzen van Zanten, S. J. (2006). Differences between tissue-associated intestinal microfloras of patients with Crohn's disease and ulcerative colitis. J. Clin. Microbiol. 44, 4136-4141.

Greten, F. R., Eckmann, L., Greten, T. F., Park, J. M., Li, Z. W., Egan, L. J., Kagnoff, M. F., and Karin, M. (2004). IKKbeta links inflammation and tumorigenesis in a mouse model of colitis-associated cancer. Cell 118, 285-296.

Grivennikov, S., Karin, E., Terzic, J., Mucida, D., Yu, G. Y., Vallabhapurapu, S., Scheller, J., Rose-John, S., Cheroutre, H., Eckmann, L., and Karin, M. (2009). IL-6 and Stat3 are required for survival of intestinal epithelial cells and development of colitis-associated cancer. Cancer Cell 15, 103-113.

Groden, J., Thliveris, A., Samowitz, W., Carlson, M., Gelbert, L., Albertsen, H., Joslyn, G., Stevens, J., Spirio, L., Robertson, M., Sargeant, L., Krapcho, K., Wolff, E., Burt, R., Hughes, J. P., Warrington, J., McPherson, J., Wasmuth, J., Le Paslier, D., Abderrahim, H., Cohen, D., Leppert, M., and White, R. (1991). Identification and characterization of the familial adenomatous polyposis coli gene. Cell 66, 589-600.

Hampe, J., Franke, A., Rosenstiel, P., Till, A., Teuber, M., Huse, K., Albrecht, M., Mayr, G., De La Vega, F. M., Briggs, J., Günther, S., Prescott, N. J., Onnie, C. M., Häsler, R., Sipos, B., Fölsch, U. R., Lengauer, T., Platzer, M., Mathew, C. G., Krawczak, M., and Schreiber, S. (2007). A genome-wide association scan of nonsynonymous SNPs identifies a susceptibility variant for Crohn disease in ATG16L1. Nat. Genet. 39, 207-211.

Harries, A. D., Baird, A., and Rhodes, J. (1982). Non-smoking: a feature of ulcerative colitis. Br. Med. J. (Clin. Res. Ed.) 284, 706.

Hedl, M., Li, J., Cho, J. H., and Abraham, C. (2007). Chronic stimulation of Nod 2 mediates tolerance to bacterial products. Proc. Natl. Acad. Sci. U.S.A. 104, 19440-19445.

Huett, A., Goel, G., and Xavier, R. J. (2010). A systems biology viewpoint on autophagy in health and disease. Curr. Opin. Gastroenterol. 26, 302-309.

Hugot, J. P., Chamaillard, M., Zouali, H., Lesage, S., Cézard, J. P., Belaiche, J., Almer, S., Tysk, C., O’Morain, C. A., Gassull, M., Binder, V., Finkel, Y., Cortot, A., Modigliani, R., LaurentPuig, P., Gower-Rousseau, C., Macry, J., Colombel, J. F., Sahbatou, M., and Thomas, G. (2001). Association of NOD2 leucine-rich repeat variants with susceptibility to Crohn's disease. Nature 411, 599-603.

Hussain, S. P., Amstad, P., Raja, K., Ambs, S., Nagashima, M., Bennett, W. P., Shields, P. G., Ham, A. J., Swenberg, J. A., Marrogi, A. J., and Harris, C. C. (2000). Increased p53 mutation load in noncancerous colon tissue from ulcerative colitis: a cancer-prone chronic inflammatory disease. Cancer Res. 60, 3333-3337.

Issa, J. P., Ahuja, N., Toyota, M., Bronner, M. P., and Brentnall, T. A. (2001). Accelerated age-related $\mathrm{CpG}$ island methylation in ulcerative colitis. Cancer Res. 61, 3573-3577.

Itzkowitz, S. H., and Yio, X. (2004). Inflammation and cancer IV. Colorectal cancer in inflammatory bowel disease: the role of inflammation. Am. J. Physiol. Gastrointest. Liver Physiol. 287, G7-G17.

Kappelman, M. D., Rifas-Shiman, S. L., Kleinman, K., Ollendorf, D., Bousvaros, A., Grand, R. J., and Finkelstein, J. A. (2007). The prevalence and geographic distribution of Crohn's disease and ulcerative colitis in the United States. Clin. Gastroenterol. Hepatol. 5, 1424-1429.

Kaser, A., Zeissig, S., and Blumberg, R. S. (2010). Inflammatory bowel disease. Annu. Rev. Immunol. 28, 573-621.

Kawanishi, S., Hiraku, Y., Pinlaor, S., and Ma, N. (2006). Oxidative and nitrative DNA damage in animals and patients with inflammatory diseases in relation to inflammation-related carcinogenesis. Biol. Chem. 387, 365-372.

Kuhn, R., Lohler, J., Rennick, D., Rajewsky, K., and Müller, W. (1993). Interleukin-10-deficient mice develop chronic enterocolitis. Cell 75, 263-274.

Kundu, J. K., and Surh, Y. J. (2008) Inflammation: gearing the journey to cancer. Mutat. Res. 659, 15-30.

Kuster, W., Pascoe, L., Purrmann, J., Funk, S., and Majewski, F. (1989). The genetics of Crohn disease: complex segregation analysis of a family study with 265 patients with Crohn disease and 5,387 relatives. Am. J. Med. Genet. 32, 105-108.

Lesage, S., Zouali, H., Cézard, J. P., Colombel, J. F., Belaiche, J., Almer, S., Tysk, C., O’Morain, C., Gassull, M., Binder, V., Finkel, Y., Modigliani, R., Gower-Rousseau, C., Macry, J., Merlin, F., Chamaillard, M., Jannot, A. S., Thomas, G., Hugot, J. P.; EPWG-IBD Group; EPIMAD Group; and GETAID Group. (2002). CARD15/NOD2 mutational analysis and genotype-phenotype correlation in 612 patients with inflammatory bowel disease. Am. J. Hum. Genet. 70, 845-857.

Liao, J., Seril, D. N., Lu, G. G., Zhang, M., Toyokuni, S., Yang, A. L., and Yang, G. Y. (2008). Increased susceptibility of chronic ulcerative colitis-induced carcinoma development in DNA repair enzyme Ogg1 deficient mice. Mol. Carcinog. 47, 638-646.

Lidar, M., Langevitz, P., and Shoenfeld, Y. (2009). The role of infection in inflammatory bowel disease: initiation, exacerbation and protection. Isr. Med. Assoc. J. 11, 558-563.

Loftus, E. V. Jr. (2007). The burden of inflammatory bowel disease in the United States: a moving target? Clin. Gastroenterol. Hepatol. 5, 1383-1384.

Manichanh, C., Rigottier-Gois, L., Bonnaud, E., Gloux, K., Pelletier, E., Frangeul, L., Nalin, R., Jarrin, C., Chardon, P., Marteau, P., Roca, J., and Dore, J. (2006). Reduced diversity of faecal microbiota in Crohn's disease revealed by a metagenomic approach. Gut 55, 205-211.

Mantovani, A., Allavena, P., Sica, A., and Balkwill, F. (2008). Cancerrelated inflammation. Nature 454, 436-444.

Meira, L. B., Bugni, J. M., Green, S. L., Lee, C.-W., Pang, B., Borenshtein, D., Rickman, B. H., Rogers, A. B., Moroski-Erkul, C. A., McFaline, J. L., Schauer, D. B., Dedon, P. C., Fox, J. G., and Samson, L. D. (2008). DNA damage induced by chronic inflammation contributes to colon carcinogenesis in mice. J. Clin. Invest. 118, 2516-2525.

Miller, B. C., Zhao, Z., Stephenson, L. M., Cadwell, K., Pua, H. H., Lee, H. K., Mizushima, N. N., Iwasaki, A.,
He, Y. W., Swat, W., and Virgin, H. W. IV. (2008). The autophagy gene ATG5 plays an essential role in B lymphocyte development. Autophagy 4, 309-314.

Mombaerts, P., Mizoguchi, E., Grusby, M. J., Glimcher, L. H., Bhan, A. K., and Tonegawa, S. (1993). Spontaneous development of inflammatory bowel disease in $\mathrm{T}$ cell receptor mutant mice. Cell 75, 274-282.

Nell, S., Suerbaum, S., and Josenhans, C. (2010). The impact of the microbiota on the pathogenesis of IBD: lessons from mouse infection models. Nat. Rev. Microbiol. 8, 564-577.

Neufert, C., Becker, C., and Neurath, M. F. (2007). An inducible mouse model of colon carcinogenesis for the analysis of sporadic and inflammation-driven tumor progression. Nat. Protoc. 2, 1998-2004.

Neurath, M. F., and Finotto, S. (2009). Translating inflammatory bowel disease research into clinical medicine. Immunity 31, 357-361.

Ogura, Y., Bonen, D. K., Inohara, N., Nicolae, D. L., Chen, F. F., Ramos, R., Britton, H., Moran, T., Karaliuskas, R., Duerr, R. H., Achkar, J. P., Brant, S. R., Bayless, T. M., Kirschner, B. S., Hanauer, S. B., Nuñez, G., and Cho, J. H. (2001). A frameshift mutation in NOD2 associated with susceptibility to Crohn's disease. Nature 411, 603-606.

Orholm, M., Binder, V., Sørensen, T. I., Rasmussen, L. P., and Kyvik, K. O. (2000). Concordance of inflammatory bowel disease among Danish twins. Results of a nationwide study. Scand. J. Gastroenterol. 35 , 1075-1081.

Pabst, O., Zweigerdt, R., and Arnold, H. H. (1999). Targeted disruption of the homeobox transcription factor Nkx2-3 in mice results in postnatal lethality and abnormal development of small intestine and spleen. Development 126, 2215-2225.

Parkes, M., Barrett, J. C., Prescott, N. J., Tremelling, M., Anderson, C. A., Fisher, S. A., Roberts, R. G., Nimmo, E. R., Cummings, F. R., Soars, D., Drummond, H., Lees, C. W., Khawaja, S. A., Bagnall, R., Burke, D. A., Todhunter, C. E., Ahmad, T., Onnie, C. M., McArdle, W., Strachan, D., Bethel, G., Bryan, C., Lewis, C. M., Deloukas, P., Forbes, A., Sanderson, J., Jewell, D. P., Satsangi, J., Mansfield, J. C.; Wellcome Trust Case Control Consortium, Cardon, L., and Mathew, C. G. (2007). Sequence variants in the autophagy gene IRGM and multiple other replicating loci contribute to Crohn's disease susceptibility. Nat. Genet. 39, 830-832. 
Pullan, R. D., Rhodes, J., Ganesh, S., Mani, V., Morris, J. S., Williams, G. T., Newcombe, R. G., Russell, M., Feyerabend, C., Thomas, G., and Sawe, U. (1994). Transdermal nicotine for active ulcerative colitis. N. Engl. J. Med. 330, 811-815.

Qin, J., Li, R., Raes, J., Arumugam, M., Burgdorf, K. S., Manichanh, C., Nielsen, T., Pons, N., Levenez, F., Yamada, T., Mende, D. R., Li, J., Xu, J., Li, S., Li, D., Cao, J., Wang, B., Liang, H., Zheng, H., Xie, Y., Tap, J., Lepage, P., Bertalan, M., Batto, J. M., Hansen, T., Le Paslier, D., Linneberg, A., Nielsen, H. B., Pelletier, E., Renault, P., Sicheritz-Ponten, T., Turner, K., Zhu, H., Yu, C., Li, S., Jian, M., Zhou, Y., Li, Y., Zhang, X., Li, S., Qin, N., Yang, H., Wang, J., Brunak, S., Doré, J., Guarner, F., Kristiansen, K., Pedersen, O., Parkhill, J., Weissenbach, J.; MetaHIT Consortium, Bork, P., Ehrlich, S. D., and Wang, J. (2010). A human gut microbial gene catalogue established by metagenomic sequencing. Nature 464, 59-65.

Quante, M., Tu, S. P., Tomita, H., Gonda, T., Wang, S. S., Takashi, S., Baik, G. H., Shibata, W., Diprete, B., Betz, K. S., Friedman, R., Varro, A., Tycko, B., and Wang, T. C. (2011). Bone marrow-derived myofibroblasts contribute to the mesenchymal stem cell niche and promote tumor growth. Cancer Cell 19, 257-272.

Rakoff-Nahoum, S., Paglino, J., EslamiVarzaneh, F., Edberg, S., and Medzhitov, R. (2004). Recognition of commensal microflora by Toll-like receptors is required for intestinal homeostasis. Cell 118, 229-241.

Redston, M. S., Papadopoulos, N., Caldas, C., Kinzler, K. W., and Kern, S. E. (1995). Common occurrence of APC and K-ras gene mutations in the spectrum of colitis-associated neoplasias. Gastroenterology 108, 383-392.

Reiff, C., and Kelly, D. (2010). Inflammatory bowel disease, gut bacteria and probiotic therapy. Int. J. Med. Microbiol. 300, 25-33.

Rosenstiel, P., Sina, C., Franke, A., and Schreiber, S. (2009). Towards a molecular risk map-recent advances on the etiology of inflammatory bowel disease. Semin. Immunol. 21, 334-345.

Rubtsov, Y., Rasmussen, J. P., Chi, E. Y., Fontenot, J., Castelli, L., Ye, X., Treuting, P., Siewe, L., Roers, A., Henderson, W. R. Jr., Muller, W., and Rudensky, A. Y. (2008). Regulatory $\mathrm{T}$ cell-derived interleukin-10 limits inflammation at environmental interfaces. Immunity 28, 546-558.
Rutter, M., Saunders, B., Wilkinson, K., Rumbles, S., Schofield, G., Kamm, M., Williams, C., Price, A., Talbot, I., and Forbes, A. (2004). Severity of inflammation is a risk factor for colorectal neoplasia in ulcerative colitis. Gastroenterology 126, 451-459.

Sadlack, B., Merz, H., Schorle, H., Schimpl, A., Feller, A. C., and Horak, I. (1993). Ulcerative colitislike disease in mice with a disrupted interleukin-2 gene. Cell 75, 253-261.

Salcedo, R., Worschech, A., Cardone, M., Jones, Y., Gyulai, Z., Dai, R. M., Wang, E., Ma, W., Haines, D., O'hUigin, C., Marincola, F. M., and Trinchieri, G. (2010). MyD88mediated signaling prevents development of adenocarcinomas of the colon: role of interleukin 18. J. Exp. Med. 207, 1625-1636.

Sandborn, W. J., Tremaine, W. J., Offord, K. P., Lawson, G. M., Petersen, B. T., Batts, K. P., Croghan, I. T., Dale, L. C., Schroeder, D. R., and Hurt, R. D. (1997). Transdermal nicotine for mildly to moderately active ulcerative colitis. A randomized, double-blind, placebo-controlled trial. Ann. Intern. Med. 126, 364-371.

Sellon, R. K., Tonkonogy, S., Schultz, M., Dieleman, L. A., Grenther, W., Balish, E., Rennick, D. M., and Sartor, R. B. (1998). Resident enteric bacteria are necessary for development of spontaneous colitis and immune system activation in interleukin-10-deficient mice. Infect. Immun. 66, 5224-5231.

Shaker, A., and Rubin, D. C. (2011). Intestinal stem cells and epithelialmesenchymal interactions in the crypt and stem cell niche. Transl. Res. 156, 180-187.

Shaker, A., Swietlicki, E. A., Wang, L., Jiang, S., Onal, B., Bala, S., DeSchryver, K., Newberry, R., Levin, M. S., and Rubin, D. C. (2010). Epimorphin deletion protects mice from inflammation-induced colon carcinogenesis and alters stem cell niche myofibroblast secretion. J. Clin. Invest. 120, 2081-2093.

Sheikh, S. Z., Hegazi, R. A., Kobayashi, T., Onyiah, J. C., Russo, S. M., Matsuoka, K., Sepulveda, A. R., Li, F., Otterbein, L. E., and Plevy, S. E. (2011). An anti-inflammatory role for carbon monoxide and heme oxygenase- 1 in chronic Th2mediated murine colitis. J. Immunol. 186, 5506-5513.

Silverberg, M. S., Cho, J. H., Rioux, J. D., McGovern, D. P., Wu, J., Annese, V., Achkar, J. P., Goyette, P., Scott, R., Xu, W., Barmada, M. M., Klei, L., Daly, M. J., Abraham, C., Bayless, T. M., Bossa, F., Griffiths, A. M., Ippoliti, A. F., Lahaie, R. G., Latiano,
A., Paré, P., Proctor, D. D., Regueiro, M. D., Steinhart, A. H., Targan, S. R., Schumm, L. P., Kistner, E. O., Lee, A. T., Gregersen, P. K., Rotter, J. I., Brant, S. R., Taylor, K. D., Roeder, K., and Duerr, R. H. (2009). Ulcerative colitis-risk loci on chromosomes 1 p36 and 12q15 found by genomewide association study. Nat. Genet. 41, 216-220.

Singh, S. B., Davis, A. S., Taylor, G. A., and Deretic, V. (2006). Human IRGM induces autophagy to eliminate intracellular mycobacteria. Science 313 , 1438-1441.

Solinas, G., Marchesi, F., Garlanda, C., Mantovani, A., and Allavena, P. (2010). Inflammation-mediated promotion of invasion and metastasis. Cancer Metastasis Rev. 29, 243-248.

Strober, W., and Fuss, I. J. (2011). Proinflammatory cytokines in the pathogenesis of inflammatory bowel diseases. Gastroenterology 140, 1756-1767.

Strober, W., Fuss, I. J., and Blumberg, R. S. (2002). The immunology of mucosal models of inflammation. Annu. Rev. Immunol. 20, 495-549.

Suzuki, R., Kohno, H., Sugie, S., Nakagama, H., and Tanaka, T. (2006). Strain differences in the susceptibility to azoxymethane and dextran sodium sulfate-induced colon carcinogenesis in mice. Carcinogenesis 27, 162-169.

Tanaka, F., Tominaga, K., Ochi, M., Tanigawa, T., Watanabe, T., Fujiwara, Y., Ohta, K., Oshitani, N., Higuchi, K., and Arakawa, T. (2008). Exogenous administration of mesenchymal stem cells ameliorates dextran sulfate sodium-induced colitis via antiinflammatory action in damaged tissue in rats. Life Sci. 83, 771-779.

Tarmin, L., Yin, J., Harpaz, N., Kozam, M., Noordzij, J., Antonio, L. B., Jiang, H. Y., Chan, O., Cymes, K., and Meltzer, S. J. (1995). Adenomatous polyposis coli gene mutations in ulcerative colitis-associated dysplasias and cancers versus sporadic colon neoplasms. Cancer Res. 55, 2035-2038.

Taurog, J. D., Richardson, J. A., Croft, J. T., Simmons, W. A., Zhou, M., Fernández-Sueiro, J. L., Balish, E., and Hammer, R. E. (1994). The germfree state prevents development of gut and joint inflammatory disease in HLA-B27 transgenic rats. J. Exp. Med. 180, 2359-2364.

Terzic, J., Grivennikov, S., Karin, E., and Karin, M. (2010). Inflammation and colon cancer. Gastroenterology 138, 2101-2114.e5.

Tsuji, S., Uehori, J., Matsumoto, M., Suzuki, Y., Matsuhisa, A., Toyoshima,
K., and Seya, T. (2001). Human intelectin is a novel soluble lectin that recognizes galactofuranose in carbohydrate chains of bacterial cell wall. $J$. Biol. Chem. 276, 23456-23463.

Turnbaugh, P. J., Ley, R. E., Hamady, M., Fraser-Liggett, C. M., Knight, R., and Gordon, J. I. (2007). The human microbiome project. Nature 449, 804-810.

Tysk, C., Lindberg, E., Järnerot, G., and Flodérus-Myrhed, B. (1988). Ulcerative colitis and Crohn's disease in an unselected population of monozygotic and dizygotic twins. A study of heritability and the influence of smoking. Gut 29, 990-996.

Ullman, T. A., and Itzkowitz, S. H. (2011). Intestinal inflammation and cancer. Gastroenterology 140, $1807-$ 1816.

Unkart, J. T., Anderson, L., Li, E., Miller, C., Yan, Y., Gu, C. C., Chen, J., Stone, C. D., Hunt, S., and Dietz, D. W. (2008). Risk factors for surgical recurrence after ileocolic resection of Crohn's disease. Dis. Colon Rectum 51, 1211-1216.

Vermeulen, L., De Sousa, E. M. F., van der Heijden, M., Cameron, K., de Jong, J. H., Borovski, T., Tuynman, J. B., Todaro, M., Merz, C., Rodermond, H., Sprick, M. R., Kemper, K., Richel, D. J., Stassi, G., and Medema, J. P. (2010). Wnt activity defines colon cancer stem cells and is regulated by the microenvironment. Nat. Cell Biol. 12, 468-476.

Watanabe, T., Kitani, A., Murray, P. J., and Strober, W. (2004). NOD2 is a negative regulator of Toll-like receptor 2-mediated $\mathrm{T}$ helper type 1 responses. Nat. Immunol. 5, 800-808.

Westbrook, A. M., Szakmary, A., and Schiestl, R. H. (2010). Mechanisms of intestinal inflammation and development of associated cancers: lessons learned from mouse models. Mutat. Res. 705, 40-59.

Worthley, D. L., Giraud, A. S., and Wang, T. C. (2010). Stromal fibroblasts in digestive cancer. Cancer Microenviron. 3, 117-125.

Wrackmeyer, U., Hansen, G. H., Seya, T., and Danielsen, E. M. (2006). Intelectin: a novel lipid raft-associated protein in the enterocyte brush border. Biochemistry 45, 9188-9197.

Yen, D., Cheung, J., Scheerens, H., Poulet, F., McClanahan, T., McKenzie, B., Kleinschek, M. A., Owyang, A., Mattson, J., Blumenschein, W., Murphy, E., Sathe, M., Cua, D. J., Kastelein, R. A., and Rennick, D. (2006). IL-23 is essential for T cell-mediated colitis and promotes inflammation via IL-17 and IL-6. $J$. Clin. Invest. 116, 1310-1316. 
Zhang, R., Ma, A., Urbanski, S. J., and McCafferty, D. M. (2007). Induction of inducible nitric oxide synthase: a protective mechanism in colitisinduced adenocarcinoma. Carcinogenesis 28, 1122-1130.

Conflict of Interest Statement: The authors declare that the research was conducted in the absence of any commercial or financial relationships that could be construed as a potential conflict of interest.

Received: 18 January 2012; paper pending published: 31 January 2012; accepted: 17 April 2012; published online: 08 May 2012
Citation: Rubin DC, Shaker $A$ and Levin MS (2012). Chronic intestinal inflammation: inflammatory bowel disease and colitis-associated colon cancer. Front. Immun. 3:107. doi: 10.3389/ fimmu.2012.00107

This article was submitted to Frontiers in Inflammation, a specialty of Frontiers in Immunology.
Copyright (๑) 2012 Rubin, Shaker and Levin. This is an open-access article distributed under the terms of the Creative Commons Attribution Non Commercial License, which permits non-commercial use, distribution, and reproduction in other forums, provided the original authors and source are credited. 